Ks. Mariusz SZRAM*

\title{
NOWOTESTAMENTALNY PARADOKS MOCNEJ SŁABOŚCI W EGZEGEZIE BIBLIJNEJ ORYGENESA
}

W 2. poł. II w. rozpoczął się w Kościele rozkwit tzw. egzegezy bezpośredniej, czyli wyjaśniania poszczególnych ksiąg biblijnych w formie rozbudowanych komentarzy lub mniej obszernych homilii. Prekursorem tej twórczości, a równocześnie jednym z jej najwybitniejszych przedstawicieli, do którego myśli nawiązywała cała egzegeza biblijna okresu patrystyki i średniowiecza, był aleksandryjski teolog Orygenes (185-253/254). Jest on znany przede wszystkim jako zwolennik alegorycznej, czyli przenośnej interpretacji tekstów biblijnych, zwłaszcza starotestamentalnych, i nadawania im sensu chrystologicznego lub duchowego w szerokim tego słowa znaczeniu, odnoszącego się do relacji człowieka z Bogiem. To duchowe ukierunkowanie egzegezy

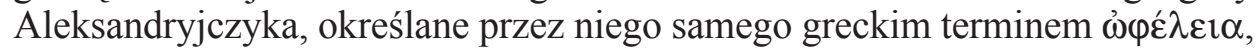
czyli „korzyść duchowa”, było w jego przekonaniu głównym celem wszelkiego rodzaju lektury Pisma Świętego, zarówno o nastawieniu naukowym, jak i moralno-ascetycznym ${ }^{1}$.

Taki duchowy charakter ma również interpretacja nowotestamentalnych tekstów zestawiających obok siebie w paradoksalny sposób pojęcia słabo-

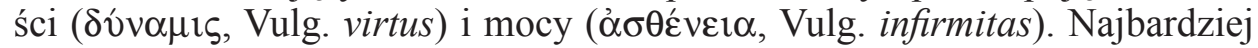
charakterystyczne z tych tekstów to ewangeliczne przesłanie ośmiu błogosławieństw, obiecujące ostateczne zwycięstwo wszystkim ludziom cierpiącym na jakiekolwiek słabości (por. Mt 5, 10-11), a przede wszystkim wypowiedzi św. Pawła, które można streścić w słowach Apostoła z 2Kor 12, 8-9: „Pan mi powiedział: «Wystarczy ci mojej łaski. Moc bowiem w słabości się doskonali». Najchętniej więc będę się chlubił z moich słabości, aby zamieszkała we mnie moc Chrystusa". Wspomniane teksty biblijne posługują się terminem „słabość" w dwojakim znaczeniu, do którego nawiązują w swoich komenta-

* Ks. prof. dr hab. Mariusz Szram - profesor zwyczajny w Katedrze Patrologii Greckiej i Łacińskiej Instytutu Historii Kościoła i Patrologii na Wydziale Teologii Katolickiego Uniwersytetu Lubelskiego Jana Pawła II; e-mail: m.szram@wp.pl.

${ }^{1}$ Por. M. Simonetti, Między dostownościq a alegoria. Przyczynek do historii egzegezy patrystycznej, thum. T. Skibiński, Kraków 2000, 71-98; H. Crouzel, Orygenes, thum. J. Margański, Bydgoszcz 1997, 97-128; M. Szram, Duchowy sens liczb w alegorycznej egzegezie aleksandryjskiej (II-V w.), Lublin 2001, 299-305. 
rzach egzegeci epoki patrystycznej. Ewangeliczne błogosławieństwa mówią o doświadczaniu różnych słabości zewnętrznych w postaci ucisków i prześladowań. Listy Pawłowe natomiast skupiają się na wewnętrznej słabości człowieka wynikającej z osłabionej grzechem własnej woli. Oba rodzaje słabości są okazją do zdobycia wewnętrznej duchowej mocy, której ostatecznym źródłem jest sam Bóg.

Przedmiotem artykułu jest wydobycie i usystematyzowanie podstawowych aspektów Orygenesowej egzegezy tekstów biblijnych dotyczących paradoksu mocnej słabości oraz osadzenie ich w realiach epoki. Egzegeza ta przebiega według pewnego schematu, który wyznaczy porządek prezentowania omawianych zagadnień. Jest ona zakorzeniona w idei naśladowania Chrystusa, który dobrowolnie przyjął słabą ludzką naturę i znosił cierpienia, ale ostatecznie dzięki mocy Bożej odniósł zwycięstwo przez zmartwychwstanie. Słabość ludzka - zarówno wynikająca z okoliczności życiowych, jak i przyjęta dobrowolnie na drodze ascezy - interpretowana jest jako okazja do ćwiczenia się w doskonałości i przyjęcia mocy Bożej, bez której człowiek - jako byt stworzony i grzeszny - jest skazany na przegraną. Cierpienia obecnego świata są postrzegane w kontekście eschatologicznym jako droga prowadząca do przyszłej radości. W tym kontekście znajduje swoje usprawiedliwienie i wyjaśnienie trudna sytuacja społeczna ludzi słabych.

1. Naśladowanie mocnej słabości Chrystusa. We wczesnochrześcijańskiej egzegezie biblijnej od początku dominował chrystocentryzm. Orygenes najpierw szukał w swojej interpretacji Starego Testamentu odniesień do Chrystusa, jako uosobionego Bożego Słowa przemawiającego przez każde słowo Pisma, a dopiero później odniesień do ludzkiej duszy i jej relacji do Boga $^{2}$. Podobnie było w przypadku interesującego nas paradoksu mocnej słabości, którego wzorem jest dla Aleksandryjczyka Jezus Chrystus. Orygenes w swojej egzegezie pozostał wierny rozpowszechnionemu w pierwszych trzech wiekach modelowi duchowości, łączącemu biblijną ideę Chrystusa cierpiącego dobrowolnie za grzechy ludzkości z okolicznościami historycznymi wynikającymi z narastających w tym okresie prześladowań chrześcijan ${ }^{3}$. Pierwsze świadectwa tego modelu odnajdujemy w listach

\footnotetext{
${ }^{2}$ Por. Origenes, Homiliae in Genesim 2, 6; tenże, Homiliae in Exodum 1, 4; 3, 3. Zob. H. de Lubac, Histoire et esprit. L'intelligence de l'Écriture d'après Origène, Paris 1950, 143-145; A. Paciorek, Alegoria i teoria, CT 67 (1997) nr 1, 64-65. W egzegezie średniowiecznej odpowiednikiem Orygenesowego sensu typologiczno-chrystologicznego stanie się sens alegoryczny, a sensu indywidualnego moralno-mistycznego - sens tropologiczny. Por. de Lubac, Histoire et esprit, s. 202.

${ }^{3}$ Por. T. Špídlik - I. Gargano - V. Grossi, Historia duchowości, III: Duchowość Ojców Kościota, tłum. K. Franczyk - J. Serafin - K. Stopa, Kraków 2004, 88: „W okresie prześladowań często powtarzano, że męczennicy za wiarę są «naśladowcami prawdziwej miłości», odzwierciedleniem Chrystusa cierpiącego"; oraz tamże, s. 260-268.
} 
św. Ignacego Antiocheńskiego, a potem w dziele De pudicitia Tertuliana ${ }^{4}$ i w Kobiercach Klemensa Aleksandryjskiego ${ }^{5}$, bezpośrednio poprzedzającego twórczość Orygenesa.

Komentując fragment 1Kor 4, 9 („Wydaje mi się, że Bóg nas wyznaczył jako ostatnich, jakby na śmierć skazanych”), Orygenes uzasadniał cierpienia chrześcijan koniecznością naśladowania ich Mistrza, który jako jedyny w historii stał się śmieciem świata ${ }^{6}$. Słabość doświadczana w ziemskim życiu była dla Aleksandryjczyka połączeniem statusu grzesznego człowieka, osłabionego przez grzech, z postawą dobrowolnego przyjęcia wszelkich zewnętrznych trudności, tak jak to zrobił Chrystus, aby wraz z Nim powstać do nowego życia, czyli zamienić słabość w moc ${ }^{7}$. Idea ta wynika - jak podkreślał Orygenes - ze słów św. Pawła z tego samego listu 2Kor 4, 7-12: „Nosimy nieustannie w ciele naszym konanie Jezusa, aby życie Jezusa objawiło się w naszym ciele" ${ }^{\text {" }}$ oraz 2Kor 12, 7-10: „Najchętniej więc będę się chlubił z moich słabości, aby zamieszkała we mnie moc Chrystusa"9.

Najpełniej idea współcierpienia z Chrystusem jako jedynej drogi do odniesienia zwycięstwa nad śmiercią i grzechem wybrzmiała w Orygenesowym komentarzu do ośmiu błogosławieństw z kazania na górze (por. Mt 5, 1011): naśladowcy Chrystusa muszą być prześladowani i nie wolno im lękać się cierpień; prorocy chcieli uniknąć doświadczania słabości i ucisku, ale one są nieodłączne od głoszenia Bożego słowa ${ }^{10}$. W tym podkreślaniu gotowości na podjęcie cierpień widać wpływ okoliczności związanych z prześladowaniami, na co wcześniej jeszcze wyraźniej zwracał uwagę Klemens Aleksandryjski, pisząc w Kobiercach, że trzeba liczyć się z męczeństwem za wiarę i z miłości do Chrystusa zdobyć się - tak jak On - na pogardę śmierci ${ }^{11}$.

\section{Słabość ludzka okazją do ćwiczenia się w doskonałości i miejscem} przyjęcia mocy Bożej. Postawa mocnej słabości Chrystusa była dla wczesnochrześcijańskich egzegetów jedyną odpowiedzią na sytuację słabości każdego człowieka, zarówno wewnętrznej, jak i doświadczanej z zewnątrz. Opis tej sytuacji egzystencjalnej jest jednym $\mathrm{z}$ istotnych tematów podejmowanych w listach przez św. Pawła w nawiązaniu do jego własnego statusu jako z jednej strony człowieka podlegającego grzesznym słabościom, z drugiej - Apostoła prześladowanego z powodu głoszonej nauki.

\footnotetext{
${ }^{4}$ Por. Tertullianus, De pudicitia $14,7$.

${ }^{5}$ Por. Clemens Alexandrinus, Stromata IV 25, 1; IV 26, 2; IV 41, 2.

${ }^{6}$ Por. Origenes, Commentarii in Evangelium Ioannis VI 284; tenże, Fragmenta in Lucam in catenis 66 (154).

${ }^{7}$ Por. tenże, Homiliae in Lucam 16, 3.

${ }^{8}$ Por. tenże, Commentarii in Evangelium Ioannis I 227; I 182; tenże, Homiliae in Librum primum Regnorum (Samueli I) 1, 18.

${ }^{9}$ Por. tenże, Homiliae in Ieremiam 14, 14.

${ }^{10}$ Por. tamże 1,$13 ; 20,8$.

${ }^{11}$ Por. Clemens Alexandrinus, Stromata IV 25, 1; IV 26, 2.
} 
Obie te okoliczności powinny być, w przekonaniu Orygenesa, okazją do podjęcia wewnętrznej walki i mobilizować człowieka do zdobywania postawy człowieka silnego duchowo. Spotykają się tutaj przesłanki ewangeliczne z filozoficznymi, zaczerpniętymi z etyki stoickiej ${ }^{12}$. W egzegezie Orygenesa obok Chrystusowego wezwania do walki o zwycięstwo nad własną słabością i nad uciskami ze strony świata pobrzmiewa idea dążenia do uniezależnienia się od

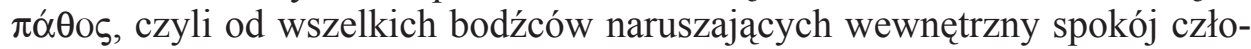
wieka, zwłaszcza od namiętności ${ }^{13}$. Tylko ci ludzie, którzy podejmą tę walkę, czyli - jak mówił Orygenes, nawiązując do obrazowania św. Pawła - przejdą od spożywania mleka i warzyw do pokarmów mięsnych, co ma świadczyć o ich dojrzałości i wewnętrznej sile, będą w stanie iść za Chrystusem i wytrwać $\mathrm{w}$ chwilach próby ${ }^{14}$. Drogą do porzucenia słabości jest ograniczenie popędów ciała, które przez swoją grzeszność i podatność na pokusy świata, stanowi szczególne siedlisko słabości, uniemożliwiającej człowiekowi osiągnięcie siły człowieka dojrzałego. Trzeba więc - paradoksalnie - osłabić słabe ciało, aby stać się prawdziwie mocnym ${ }^{15}$.

Powyższą ideę osłabienia popędów słabego ciała w procesie doskonalenia duchowego rozwinął Aleksandryjczyk w oryginalnym alegorycznym komentarzu do trzech tekstów z Księgi Jozuego, mówiących o trójstopniowym podporządkowaniu społecznym mieszkańców ziemi Kanaan, symbolizujących ludzkie ciało i jego słabości ${ }^{16}$. W pierwszym tekście (por. Joz 16, 10) Kanaanita płaci podatki, lecz nie jest poddanym ani niewolnikiem. To alegoria ciała, które jest połączone z duszą, jednak jej nie podlega. Płaci jedynie podatki, to znaczy służy do jakichś działań, ale pożąda przeciwko duchowi i nie jest posłuszne duszy, lecz własnym pragnieniom. Kanaanita z drugiego tekstu (por. Joz 17,13 ) pełni rolę sługi. W znaczeniu duchowym oznacza to - według Orygenesa - że postępy w walce ze słabym ciałem sprawiają iż staje się ono sługą człowieka i jest posłuszne woli duszy. Trzeci tekst (por. Joz 17, 14n; zob. Kol 3, 5; Ga 5, 24) mówi o poleceniu zgładzenia Kanaanity i wydania go na śmierć. W znaczeniu duchowym oznacza to dojście do doskonałości i zdobycie duchowej mocy przez uśmiercenie popędów słabego ciała ${ }^{17}$.

Idea zachęty do zdobywania wewnętrznej siły w sytuacji wewnętrznej i zewnętrznej słabości pojawiała się wcześniej w środowisku aleksandryjskim u Klemensa Aleksandryjskiego. Powołując się na Platona, który w dialogu

${ }^{12}$ Por. M. Spanneut, Le stoïcisme des Pères de l'Église. De Clément de Rome à Clément d'Alexandrie, Paris 1957, 204. 427; Špídlik - Gargano - Grossi, Historia duchowości, III, s. 1718; M. Kozera, Ideaty Ojców Pustyni. Pathos i apatheia, Lublin 2000, 59-123.

${ }^{13}$ Por. Špídlik - Gargano - Grossi, Historia duchowości, III, s. 129-133.

${ }^{14}$ Por. Origenes, Homiliae in Exodum 7, 1; tenże, Homiliae in Iesu Nave 9, 9; tenże, Homiliae in Numeros 27, 1; tenże, Commentariorum in Matthaeum Series 91.

${ }^{15}$ Por. tenże, Commentariorum in Matthaeum Series 94; tenże, Commentarium in Evangelium Matthaei 13, 16.

${ }^{16}$ Por. tenże, Homiliae in Iesu Nave 22, 2.

${ }^{17}$ Por. tamże. 
Państwo stwierdził, że człowiek sprawiedliwy, nawet jeśli zostanie poddany torturom i wyłupią mu oczy, będzie jednak szczęśliwy ${ }^{18}$, Klemens pisał, że słabość fizyczna nie może zniszczyć hartu ducha. Wręcz przeciwnie, powinna ona być - tym razem w duchu stoickim - okazją do zwycięstwa nad namiętnościami, odniesionym przez prawdziwego gnostyka - jak Klemens nazywał doskonałego chrześcijanina ${ }^{19}$. Podobne wypowiedzi spotykamy na przełomie II i III w. także w pismach apologetów, np. u Tacjana Syryjczyka ${ }^{20}$, Tertuliana ${ }^{21}$ i Minucjusza Feliksa ${ }^{22}$.

Powyższa idea, mimo skojarzeń ze stoicką $\alpha \operatorname{ló} \theta \varepsilon ı$, miała u Orygenesa i jego współczesnych wyraźny kontekst teologiczny. Słabość wewnętrzna i zewnętrzna nie jest dana człowiekowi po to, aby pokonywał ją swoimi siłami - które są przecież słabe - i dochodził do postawy doskonałości wyłącznie drogą własnych wysiłków, jak stoicki mędrzec. Orygenes, komentując św. Pawła, akcentował wyraźnie, że słabość ta może być pokonana tylko we współpracy z Bożą łaską i jest okazją do okazania mocy Bożej w ludzkim życiu ${ }^{23}$. W komentarzu do Listu do Rzymian Orygenes za Apostołem podkreślił, że nie można chlubić się własną mądrością i siłą, a jedynie Bogiem ${ }^{24}$. Potwierdzeniem tej prawidłowości były dla Aleksandryjczyka słowa Psalmu: „W utrapieniu podniosłeś mnie” (Ps 4, 2), interpretowane jako wskazanie na Boga, który jako jedyny ma siłę pokonać wszelką ludzką słabość ${ }^{25}$. Podobnie jak Bóg stworzył ziemię swoją mocą, tak też człowiek na swojej ziemi - tu pojawia się aluzja do powiedzenia Adamowi przez Boga ,jesteś ziemią" (por. Rz 3, 19) - potrzebuje mocy Boga ${ }^{26}$, dlatego posłał On swojego Syna jako Zbawcę w sytuacji grzesznej słabości człowieka. Inne starotestamentalne zdarzenie, które stało się dla Aleksandryjczyka potwierdzeniem siły Boga jako jedynego lekarstwa na ludzką słabość, to urodziny Izaaka, które dokonały się dzięki interwencji Boga, a nie dzięki płodności ciała podeszłych w latach rodziców: Abrahama i Sary ${ }^{27}$.

Orygenes za św. Pawłem, ale także w zgodności z innymi autorami chrześcijańskimi II w., takimi jak: Klemens Aleksandryjski ${ }^{28}$, Tertulian ${ }^{29}$ czy Ireneusz z Lyonu ${ }^{30}$, traktował wszelką ludzką słabość jako swoistą „błogosławioną

\footnotetext{
${ }^{18}$ Por. Plato, Respublica II 361.

${ }^{19}$ Por. Clemens Alexandrinus, Stromata IV 51, 2, 272; VII 20, 4, 14.

${ }^{20}$ Por. Tatianus Syrensis, Oratio ad Graecos 11.

${ }^{21}$ Por. Tertullianus, Adversus Marcionem I 29, 6.

${ }^{22}$ Por. Minucius Felix, Octavius 36, 8.

${ }^{23}$ Por. Origenes, Commentarium in Epistulam ad Romanos 6, 9.

${ }^{24}$ Por. tamże 4, 9.

${ }^{25}$ Por. tenże, De oratione $30,1$.

${ }^{26}$ Por. tenże, Homiliae in Ieremiam 8.

${ }^{27}$ Por. tenże, Homiliae in Genesim 3, 7.

${ }^{28}$ Por. Clemens Alexandrinus, Quis dives salvetur 34, 1.

${ }^{29}$ Por. Tertullianus, Adversus Marcionem V 11, 14-16.

${ }^{30}$ Por. Irenaeus, Adversus haereses V 13, 4-5.
} 
winę", dzięki której może ukazać się Boża siła. W Komentarzu do Listu św. Pawła do Rzymian pisał, że przez uciski człowiek umacnia się w cnotach i staje się otwarty na działanie Ducha Świętego, a wszelkie słabości, doświadczane przez wielu świętych, należy traktować jako okazję do otwarcia serca na swobodniejsze działanie Boga ${ }^{31}$.

Moc Boga jako konieczne remedium na ludzką słabość omawiał Orygenes w różnych kontekstach, nie tylko w odniesieniu do życia duchowego każdego indywidualnego człowieka, ale także w perspektywie ogólnodziejowej, uniwersalnej. Fundamentalne, ramowe są dwa momenty w historii: ukazanie mocy Bożej w akcie stwórczym i zbawczym. Pojawiają się jednak w pismach egzegetycznych Aleksandryjczyka także inne płaszczyzny, na których moc Boża zwyciężyła ludzką słabość. Pierwszą z nich jest pokonanie pogańskiej religii i antycznej filozofii przez mądrość Chrystusa, wątek tematyczny obecny we współczesnej Orygenesowi literaturze apologetycznej ${ }^{32}$. Według Aleksandryjczyka biblijnym obrazem, będącym alegorią tego procesu, są trąby niszczące mury Jerycha ${ }^{33}$.

Druga płaszczyzna wiąże się z samym Pismem Świętym i jest refleksem metody egzegetycznej Orygenesa, łączącej platoński dualizm z Chrystusową deklaracją wypełnienia litery duchem. Otóż w całej Biblii słaba litera Pisma ukrywa, jak pod zasłoną (velamen litterae), moc Słowa Bożego; przez słowo przez małe „s” przemawia Słowo przez duże „S”, czyli sam Boski Logos. Pawłowe słowa o ,skarbie noszonym w glinianym naczyniu” według Orygenesa można interpretować jako przeogromną moc Boga ukrytą w prostym i lekceważonym przez Greków języku Pisma ${ }^{34}$. Odnalezienie w Piśmie tej siły znaczenia duchowego i przekazywanie go innym jest możliwe - jak podkreślał Orygenes - również tylko dzięki mocy Bożej, a nie dzięki ludzkiej mądrości ${ }^{35}$.

\section{Cierpienia w obecnym świecie zapowiedzią przyszłego zwycięstwa.}

Walka duchowa, podczas której ludzka słabość wewnętrzna i zewnętrzna staje się okazją do przyjęcia mocy Bożej, jest - według Orygenesa - znakiem czasu obecnego świata, który jest przejściowy i prowadzi do ostatecznego triumfu, wykraczającego poza ziemską rzeczywistość. Obecna słabość zmierza nieuchronnie do ostatecznego pokazu Bożej siły, który dokona się w czasach

\footnotetext{
${ }^{31}$ Por. Origenes, Commentarium in Epistulam ad Romanos 4, 9; 2, 6.

${ }^{32}$ Por. M. Szram, Apologeci wczesnochrześcijańscy, w: Leksykon teologii fundamentalnej, red. M. Rusecki - K. Kaucha - I.S. Ledwoń - J. Mastej, Lublin - Kraków 2002, 71-78; tenże, Chrystus - Mądrość Boża a madrość władców tego świata wedtug Orygenesa, w: Ojcowie Kościoła wobec filozofii i kultury klasycznej. Zagadnienia wybrane, red. F. Drączkowski - J. Pałucki - M. Szram, Lublin 1998, 110-115 i 125-127; L. Misiarczyk, Wstęp. Apologetyka wczesnochrześcijańska, w: Pierwsi apologeci greccy, BOK 24, Kraków 2004, $72-77$.

${ }^{33}$ Por. Origenes, Homiliae in Iesu Nave 7, 1.

${ }^{34}$ Por. tenże, Commentarii in Evangelium Ioannis I 24; tenże, Homiliae in Numeros 9, 6.

${ }^{35}$ Por. tenże, De principiis IV 1, 7.
} 
eschatologicznych, co Aleksandryjczyk podkreśla komentując Chrystusowe błogosławieństwa z kazania na górze ${ }^{36}$.

Ta idea ostatecznego zwycięstwa Bożej mocy nad ludzką słabością, która dokona się przez powszechne zmartwychwstanie, była szczególnie żywa w okresie narastających prześladowań chrześcijan. Odnajdujemy ją u najważniejszych autorów przełomu II i III w.: Ireneusza ${ }^{37}$, Tertuliana ${ }^{38}$ czy Klemensa Aleksandryjskiego. Ten ostatni w swoich Stromatach zachęcał wręcz do chętnego poddawania się wszelkim uciskom, aż do oddania życia, aby jak najprędzej odejść do rzeczywistości, w której człowiek nie będzie już doświadczać żadnej słabości ${ }^{39}$.

\section{Przeżywanie trudnych kwestii społecznych w świetle paradoksu} mocnej słabości. Nowotestamentalny paradoks mocnej słabości i jego ukierunkowanie na ostateczne rozwiązanie w eschatologii nakazywał pierwszym chrześcijanom ze spokojem przepojonym wiarą podchodzić do trudnych kwestii społecznych, w których doświadczenie słabości było szczególnie dotkliwe, jak np. problem niewolnictwa ${ }^{40}$. Nie szukanie rewolucyjnych rozwiązań w tym zakresie znajduje uzasadnienie w zaleceniu św. Pawła z 1Kor 7, 20-22: „Każdy przeto niech pozostanie w takim stanie, w jakim został powołany. Zostałeś powołany jako niewolnik? Nie martw się! Owszem, nawet jeśli możesz stać się wolnym, raczej skorzystaj [z twego niewolnictwa!] Albowiem ten, kto został powołany w Panu jako niewolnik, jest wyzwoleńcem Pana”.

Wszyscy ważniejsi autorzy chrześcijańscy pierwszych trzech wieków - Ignacy Antiocheński ${ }^{41}$, Tertulian ${ }^{42}$, Klemens Aleksandryjski ${ }^{43}$ czy wreszcie Orygenes - komentując te słowa podkreślają, że stan niewolnictwa jest okazją do walki duchowej o prawdziwą wolność wewnętrzną, którą daje Chrystus. Według Klemensa, jeśli chrześcijanin zostanie nawet pozbawiony praw obywatelskich, wygnany z kraju, pozbawiony mienia czy wreszcie skazany na śmierć, to jednak nigdy nie da się pozbawić swojej wewnętrznej wolności ${ }^{44}$. Orygenes w Komentarzu do Listu św. Pawła do Rzymian stwierdził, że cierpliwe znoszenie różnych słabości wynikających ze statusu niewolniczego jest okazją do solidaryzowania się z tymi, którzy są w jeszcze gorszej sytuacji ${ }^{45}$, oraz zapowiedzią wkraczania w nowe lepsze życie,

\footnotetext{
${ }^{36}$ Por. tenże, Commentarium in Epistulam ad Romanos 7, 4.

${ }^{37}$ Por. Irenaeus, Adversus haereses V 2, 3; V 3, 3.

${ }^{38}$ Por. Tertullianus, Adversus Marcionem V 11, 14-16.

${ }^{39}$ Por. Clemens Alexandrinus, Stromata IV 79, 1.

${ }^{40}$ Por. P. Szczur, Kościót Apostolski o wyzwalaniu niewolników. Zarys problematyki, VoxP 36 (2016) t. 65, 617-629.

${ }^{41}$ Por. Ignatius Antiochenus, Epistula ad Romanos 4, 3.

${ }^{42}$ Por. Tertullianus, De corona militis 13, 5; tenże, De idololatria 18, 5.

${ }^{43}$ Por. Clemens Alexandrinus, Stromata III 79, 7.

${ }^{44}$ Por. tamże IV 52, 3.

${ }^{45}$ Por. Origenes, Commentarium in Epistulam ad Romanos 10, 6.
} 
w którym okaże się moc zmartwychwstania ${ }^{46}$. Komentując w Homiliach do Ewangelii św. Łukasza osiem błogosławieństw, Aleksandryjczyk podkreślił natomiast, że pocieszeniem dla ludzi słabych i doświadczanych przez życie powinna być świadomość, iż nawet największe uciski, jakich doznaje człowiek, są niczym w porównaniu z cierpieniem Jezusa, który za ludzkie grzechy został ukrzyżowany ${ }^{47}$. Tak więc - jak pisał Orygenes w Komentarzu do Ewangelii św. Mateusza - lekceważenie w świecie i brak czci, czyli oznaki skrajnej słabości, nie powinny napawać smutkiem czy lękiem, ale stanowić pragnienie chrześcijanina i być znakiem jego wiary w ostateczne okazanie siły przez Boga ${ }^{48}$.

Orygenes, komentując nowotestamentalne teksty związane z paradoksem mocnej słabości, pozostał wierny rozpowszechnionemu w pierwszych trzech wiekach chrześcijaństwa radykalnemu rozumieniu zarówno ośmiu błogosławieństw, jak i zachęt zawartych w listach św. Pawła. W przekonaniu Aleksandryjczyka wszelka ludzka słabość - wynikająca zarówno z własnych grzechów, jak i z ucisków doznawanych z zewnątrz - jest sytuacją, którą należy wykorzystać jako okazję do podjęcia walki duchowej i przyjęcia mocy Bożej, bez której człowiek nie jest w stanie pokonać żadnych trudności. Interpretacja ta jest odbiciem kilku okoliczności tamtej epoki: pobożności męczeńskiej, polegającej na pragnieniu upodobnienia się do Chrystusa cierpiącego; konieczności znalezienia teologicznego uzasadnienia dla różnych doświadczeń sprawiających, że człowiek znajdował się w sytuacji skrajnej słabości, takich jak: prześladowania za wiarę czy praktyka niewolnictwa; wreszcie przekonania, że ostateczne zwycięstwo jest blisko, wynikającego z rozumianych dosłownie słów Chrystusa o powrocie Chrystusa i końcu świata, zanim przeminie to pokolenie (por. Mt $24,34)$. Wypracowany na bazie biblijnego paradoksu mocnej słabości model duchowości, polegającej na znoszeniu cierpień w łączności z Chrystusem i z pomocą Jego Boskiej siły, stał się nieodzownym składnikiem chrześcijańskiej pobożności także w późniejszych epokach. Mógł być on swoistym lekarstwem na przywiązanie do ludzkich możliwości w walce duchowej z namiętnościami, co było dziedzictwem skrajnie pojmowanej etyki stoickiej i mogło mieć wpływ na rozwój późniejszych ruchów ograniczających rolę mocy łaski Bożej w walce z własnymi słabościami, takich jak np. pelagianizm.

\footnotetext{
${ }^{46}$ Por. tamże 5, 10.

${ }^{47}$ Por. tenże, Homiliae in Lucam 38, 1-2.

${ }^{48}$ Por. tenże, Commentarium in Evangelium Matthaei 10, 18.
} 


\section{THE NEWTESTAMENTAL PARADOX OF STRONG WEAKNESS IN THE BIBLICAL EXEGESIS OF ORIGEN}

\section{(Summary)}

The subject of the article is the extraction and systematization of the basic aspects of Origen's exegesis of biblical texts on the paradox of strong weakness (Mt 5, 10-11; 2Cor 12, 8-9) and embedding them in the realities of the epoch. According to Origen all human weakness - resulting both from man's own sins and from the oppression experienced from outside - is a situation that should be used as an opportunity to take up spiritual fight and to accept God's power, without which man is unable to overcome any difficulties. This interpretation reflects several circumstances of that era: martyr's piety, consisting in a desire to become like Christ suffering; the necessity of finding a theological justification for various experiences that make a person in a situation of extreme weakness, such as: persecution for faith or the practice of slavery; and finally, the conviction that the final victory is close, resulting from literally understood words of Christ about His return and the end of the world, before this generation passes away (cf. Mt $23,34)$. The model of spirituality, developed on the basis of the biblical paradox of strong weakness and consisting in enduring suffering in connection with Christ and with the help of His divine power, has become an indispensable component of Christian piety also in later epochs. It could be a kind of medicine for being too attached to the own human capabilities in spiritual struggle with passions, which was the legacy of extremely conceived stoic ethics and could influence the development of later movements limiting the power of God's grace in the fight against own weaknesses, such as Pelagianism.

Key words: Origen, biblical exegesis, weakness, power.

Słowa kluczowe: Orygenes, egzegeza biblijna, słabość, moc.

\section{BIBLIOGRAFIA Źródła}

Clemens Alexandrinus, Quis dives salvetur, ed. L. Fruchtel, GCS 17, Klemens Werke 3, Berlin 1970, 159-191, tłum. J. Czuj: Klemens Aleksandryjski, Który człowiek bogaty może być zbawiony?, MBOK 2, Kraków - Ząbki 1995.

Clemens Alexandrinus, Stromata, ed. L. Fruchtel, I-VI, GCS 52(15), Klemens Werke 2, Berlin 1960; VII-VIII, GCS 17, Klemens Werke 3, Berlin 1970, thum. J. Niemirska-Pliszczyńska: Klemens Aleksandryjski, Kobierce zapisków filozoficznych dotyczqcych prawdziwej wiedzy, t. 1-2, Warszawa 1994.

Ignatius Antiochenus, Epistulae, ed. P.-Th. Camelot, SCh 10, Paris 1969, thum. A. Świderkówna: Św. Ignacy Antiocheński, Listy, PSP 45, Warszawa 1990, 66-95.

Irenaeus, Adversus haereses, ed. A. Rousseau - L. Doutreleau - B. Hemmerdinger - Ch. Mercier, I, SCh 263-264, Paris 1979; II, SCh 293-294, Paris 1982; III, SCh 210-211, Paris 1974; IV, SCh 100/1-2, Paris 1965; V, SCh 152-153, Paris 1969. 
Minucius Felix, Octavius, ed. C. Halm, CSEL 2, Vindobonae 1867, 1-56, tłum. M. Szarmach: Minucjusz Feliks, Oktawiusz, PSP 44, Warszawa 1988, 20-77.

Origenes, Commentarii in Evangelium Ioannis, ed. C. Blanc, I-V, SCh 120, Paris 1966; VI, X, SCh 157, Paris 1970; XIII, SCh 222, Paris 1975; XIX-XX, SCh 290, Paris 1982; XXVIII-XXXII, SCh 385, Paris 1992; thum. S. Kalinkowski: Orygenes, Komentarz do Ewangelii według św. Jana, ŹMT 27, Kraków 2003.

Origenes, Commentariorum in Matthaeum Series, ed. E. Klostermann - E. Benz, GCS 38, OW 11, Leipzig 1933, thum. K. Augustyniak: Orygenes, Komentarz do Ewangelii według św. Mateusza (Część druga: Commentariorum series), ŹMT 25, Kraków 2002.

Origenes, Commentarium in Epistulam ad Romanos, PG 14, 833-1292, tłum. S. Kalinkowski: Orygenes, Komentarz do Listu św Pawła do Rzymian, PSP 57, cz. 1-2, Warszawa 1994.

Origenes, Commentarium in Evangelium Matthaei, ed. R. Girod, X-XI, SCh 162, Paris 1970; ed. E. Klostermann - E. Benz, XII-XVII, GCS 40, OW 10, Leipzig 1935; thum. K. Augustyniak: Orygenes, Komentarz do Ewangelii wedtug św. Mateusza, ŹMT 10, Kraków 1998.

Origenes, De oratione, ed. P. Koetschau, GCS 3, OW 2, Leipzig 1899, 295-403, thum. W. Kania - H. Pietras: Orygenes, O modlitwie, w: Odpowiedź na Słowo. Najstarsi mistrzowie chrześcijańskiej modlitwy, red. H. Pietras, Kraków 1993, 101-240.

Origenes, De principiis, ed. H. Crouzel - M. Simonetti, I-II, SCh 252-253, Paris 1978; III-IV, SCh 268-269, Paris 1980; Compléments et index, SCh 312, Paris 1984; thum. S. Kalinkowski: Orygenes, O zasadach, ŹMT 1, Kraków 1996.

Origenes, Fragmenta in Lucam in catenis, ed. H. Crouzel - F. Fornier - P. Perichon, SCh 87, Paris 1962, 464-547, thum. S. Kalinkowski: Orygenes, Fragmenty greckie o Ewangelii św. Łukasza, PSP 36, 147-180.

Origenes, Homiliae in Exodum, ed. M. Borret, SCh 321, Paris 1985, tłum. S. Kalinkowski: Orygenes, Homilie o Księdze Wyjścia, PSP 31/1, Warszawa 1985, 21-154.

Origenes, Homiliae in Genesim, ed. H. de Lubac - L. Doutreleau, SCh 7bis, Paris 1996, tłum. S. Kalinkowski: Orygenes, Homilie o Księdze Rodzaju, PSP 31/1, Warszawa $1985,155-278$.

Origenes, Homiliae in Ieremiam, ed. P. Husson - P. Nautin, SCh 232, 238, Paris 19761977, tłum. S. Kalinkowski: Orygenes, Homilie o Księdze Jeremiasza, PSP 30, Warszawa 1986, 23-211.

Origenes, Homiliae in Iesu Nave, ed. A. Jaubert, SCh 71, Paris 1960, thum. S. Kalinkowski: Orygenes, Homilie o Księdze Jozuego, PSP 34/2, Warszawa 1986, 3-137.

Origenes, Homiliae in Librum primum Regnorum (Samueli I), ed. P. i M.-T. Nautin, SCh 328, Paris 1986, tłum. S. Kalinkowski: Orygenes, Homilie o Księach Samuela i Księgach Królewskich, PSP 30, Warszawa 1983, 287-319.

Origenes, Homiliae in Lucam, ed. H. Crouzel - F. Fornier - P. Perichon, SCh 87, Paris 1962, tłum. S. Kalinkowski: Orygenes, Homilie o Ewangelii św. Lukasza, PSP 36, Warszawa 1986.

Origenes, Homiliae in Numeros, ed. L. Doutreleau, t. 1, SCh 415, Paris 1996; t. 2, SCh 442, Paris 1999; t. 3, SCh 461, Paris 2001; tłum. S. Kalinkowski, Orygenes, Homilie o Księdze Liczb, PSP 34/1, Warszawa 1986.

Plato, Respublica, ed. S.R. Slings, Oxford 2003, tłum. W. Witwicki: Platon, Państwo, t. 1-2, Warszawa 1991.

Tatianus Syrensis, Oratio ad Graecos, ed. J.C.Th. Otto, Corpus Apologetarum Christianorum saeculi secundi, VI, Wiesbaden 1969 (przedruk wyd. z 1851 r.), 2-162, thum. L. Misiarczyk: Tacjan Syryjczyk, Mowa do Greków, BOK 24, Kraków 2004, 311-366. 
Tertullianus, Adversus Marcionem, ed. A. Kroymann, CCL 1, Turnhout 1954, 441-726, thum. S. Ryznar, Przeciw Marcjonowi, PSP 58, Warszawa 1994.

Tertullianus, De corona militis, ed. A. Kroymann, CCL 2, Turnhout 1954, 1037-1065, tłum. T. Skibiński: Tertulian, O wieńcu, w: Tertulian, Wybór pism, III, PSP 65, Warszawa 2007, 107-124.

Tertullianus, De idololatria, ed. A. Reifferscheid - G. Wissowa, CCL 2, Turnhout 1954, 1099-1124, tłum. K. Obrycki: Tertulian, O batwochwalstwie, w: Tertulian, Wybór pism, III, PSP 65, Warszawa 2007, 127-151.

Tertullianus, De pudicitia, ed. E. Dekkers, CCL 2, Turnhout 1954, 1279-1330, tłum. K. Obrycki: Tertulian, O wstydliwości, w: Tertulian, Wybór pism, III, PSP 65, Warszawa 2007, 199-248.

\section{Opracowania}

Crouzel H., Orygenes, tłum. J. Margański, Bydgoszcz 1997.

Kozera M., Ideały Ojców Pustyni. Pathos i apatheia, Lublin 2000.

LuBAC H. DE, Histoire et esprit. L'intelligence de l'Écriture d'après Origène, Paris 1950.

MisiarczyK L., Wstęp. Apologetyka wczesnochrześcijańska, w: Pierwsi apologeci greccy, BOK 24, Kraków 2004, 11-91.

Paciorek A., Alegoria i teoria, CT 67 (1997) nr 1, 64-65.

Simonetti M., Między dosłownościa a alegoriq. Przyczynek do historii egzegezy patrystycznej, tłum. T. Skibiński, Kraków 2000.

Spanneut M., Le stoïcisme des Pères de l'Église. De Clément de Rome à Clément d'Alexandrie, Paris 1957.

Špídlik T. - Gargano I. - Grossi V., Historia duchowości, III: Duchowość Ojców Kościoła, tłum. K. Franczyk - J. Serafin - K. Stopa, Kraków 2004.

Szczur P., Kościól Apostolski o wyzwalaniu niewolników. Zarys problematyki, VoxP 36 (2016) t. 65, 617-629.

Szram M., Chrystus - Madrość Boża a maqdrość władców tego świata wedtug Orygenesa, w: Ojcowie Kościoła wobec filozofii i kultury klasycznej. Zagadnienia wybrane, red. F. Drączkowski - J. Pałucki - M. Szram, Lublin 1998, 99-132.

Szram M., Apologeci wczesnochrześcijańscy, w: Leksykon teologii fundamentalnej, red. M. Rusecki - K. Kaucha - I.S. Ledwoń - J. Mastej, Lublin - Kraków 2002, 71-78.

Szram M., Duchowy sens liczb w alegorycznej egzegezie aleksandryjskiej (II-Vw.), Lublin 2001. 
